2014, volume 3, issue 2

Kirillova N. (2014). Regulation of financial condition insurers in the Russian Federation and Assessment the Insurers by Insured. Copernican Journal of Finance \& Accounting, 3(2), 79-89. http://dx.doi.org/10.12775/CJFA.2014.019

\author{
Nadezda KiriLLova* \\ Financial University under the Government of Russian Federation
}

\title{
REGULATION OF FINANCIAL CONDITION INSURERS \\ IN THE RUSSIAN FEDERATION \\ AND ASSESSMENT THE INSURERS BY INSURED
}

Keywords: regulation of the financial condition, Russian insurance companies.

J E L Classification: G18, G22.

Abstract: In the article describes the main regulations for the financial condition of Russian insurance companies: examined statutory capital requirements of insurers, the solvency margin, formation and placement the insurance reserves, covering equity by assets; are given the main characteristics of indicators, identifies areas of development; used data from supervisory authorities of the Russian Federation, the official statistics, the results of research consulting, insurance data, regulatory framework; based on the results of the article conclusions are drawn on adequate regulation of insurers' financial stability in the modern Russian insurance market and the necessity to compliance with legal requirements; made the assumption that there is no necessity to tighten regulatory requirements for companies.

\section{REGULACJE FINANSOWE RYNKU UBEZPIECZEŃ W FEDERACJI ROSYJSKIEJ ORAZ OCENA DZIAEALNOŚCI FIRM UBEZPIECZENIOWYCH PRZEZ UBEZPIECZONYCH}

Słowa kluczowe: regulacja kondycji finansowej, rosyjskie firmy ubezpieczeniowe.

Date of submission: August 17, 2014; date of acceptance: September 30, 2014.

* Contact information: nvk_66@mail.ru, Financial University under the Government of the Russian Federation, 49 Leningradsky Prospekt, Moscow, Russia, phone: +79151473221. 
Klasyfikacja J E L: G18, G22.

Abstrakt: W artykule przedstawiono podstawowe regulacje dotyczące sytuacji finansowej rosyjskich firm ubezpieczeniowych: zbadano ustawowe wymogi kapitałowe ubezpieczycieli, margines wypłacalności oraz tworzenie i rozwiązywanie rezerw ubezpieczeniowych. Zaprezentowano również główne wskaźniki identyfikujące obszary rozwoju rynku ubezpieczeniowego.

W pracy wykorzystano dane pochodzące z organów nadzoru Federacji Rosyjskiej, oficjalnych statystyk, wyników badań obcych, danych doradztwa ubezpieczeniowego oraz odpowiednich przepisów regulacyjnych.

Na podstawie wyników przeprowadzonych badań przedstawiających regulacje w zakresie stabilności finansowej zakładów ubezpieczeń na współczesnym rosyjskim rynku ubezpieczeń wskazano, że nie ma konieczności, aby zwiększać wymogi regulacyjne dla tych przedsiębiorstw.

\section{INTRODUCTION}

Insurer financial strength is a major factor in the implementation of insurance liabilities. Currently, insurance becomes one of the real instruments to support the financial condition of the enterprises, the quality of life, solution of social problems, along with the implementation of the investment function.

Russian insurance market in 2013 slowed his development. Return on equity of Russian insurance companies in 2013 was equal to 6\% (minimum within five years) (Jurgens 2014). Currently the companies of Russian insurance market, table 1 , are faced with many challenges.

Table 1. Premiums and payments (type of insurance) in Russian Federation, 2013

\begin{tabular}{|l|c|c|c|c|c|c|}
\hline \multirow{2}{*}{\multicolumn{1}{c}{ Type of insurance }} & \multicolumn{3}{c|}{ Premiums } & \multicolumn{2}{c|}{ Payments } \\
\cline { 2 - 7 } & Bln. rub. & $\%$ & $\begin{array}{c}\% \\
\text { prev. year }\end{array}$ & Bln.rub & $\%$ & prev. year \\
\hline \hline Life insurance & 84.89 & 9.4 & 160.5 & 12.33 & 2.9 & 92.4 \\
\hline Personal insurance (non life) & 208.73 & 23.1 & 113.2 & 103.14 & 24.5 & 110.9 \\
\hline Property insurance & 393.82 & 43.5 & 104.6 & 201.73 & 48.0 & 111.0 \\
\hline Liability insurance & 29.74 & 3.3 & 99.4 & 7.14 & 1.7 & 133.0 \\
\hline Business and financial risks & 21.95 & 2.4 & 110.2 & 1.66 & 0.4 & 79.4 \\
\hline Total voluntary insurance & 739.13 & 81.7 & 111.4 & 326.0 & 77.5 & 110.3 \\
\hline $\begin{array}{l}\text { Compulsory insurance of civil liability } \\
\text { motor owners }\end{array}$ & 134.25 & 14.8 & 110.3 & 77.37 & 18.4 & 119.0 \\
\hline
\end{tabular}




\begin{tabular}{|l|c|c|c|c|c|c|}
\hline \hline \multirow{2}{*}{\multicolumn{1}{c}{ Type of insurance }} & \multicolumn{3}{c|}{ Premiums } & \multicolumn{3}{c|}{ Payments } \\
\cline { 2 - 7 } & Bln. rub. & $\%$ & $\begin{array}{c}\% \\
\text { prev. year }\end{array}$ & Bln.rub & $\%$ & $\begin{array}{c}\% \\
\text { prev. year }\end{array}$ \\
\hline \hline Other than medical and motorcycle & 31.48 & 3.5 & 109.4 & 17.4 & 4.1 & 144.9 \\
\hline Total compulsory & 165.73 & 18.3 & 110.2 & 94.77 & 22.5 & 123.1 \\
\hline Total voluntary and compulsory & 904.86 & 100.0 & 111.1 & 420.77 & 100.0 & 112.9 \\
\hline \hline
\end{tabular}

S o u r c e : The Central Bank of the Russian Federation.

In recent years, the basic system calls became a sharp increase in the requirements for the minimum authorized capital, the wave of lawsuits on complaints of policyholders to delay and the refusal insurance payments (mainly on compulsory motor TPL insurance), the last massive insurance claims in insurance tourists (compensation according to various estimates may be required 25 thousands of tourists; for example, the insurance company "Military Insurance Company" in August, took two days about 12 thousand applications from customers of travel agency "Labyrinth" for a total amount of 453 million rubles) (All-Russian Insurance Association 2014). However, their main task is to perform insurance liabilities. Consider the basic requirements for the financial condition of Russian insurers.

\section{THE RESEARCH METHODOLOGY AND THE COURSE OF THE RESEARCH PROCESS}

The aim of the paper is to present author's approach to the identification of the financial condition of Russian insurance companies. The author will analyze the legal requirements for the financial condition of Russian insurers. Also, the author will How to change the qualitative and quantitative status of insurance companies, depending on the requirements imposed on them. The paper is divided into two major parts. The first part is related to characteristic the basic regulatory requirements for the financial condition of insurance companies in Russia. Author presents in detail the legal requirements for minimum registered capital, requirements for the formation (composition) and the placement of insurance reserves and the covering own funds by assets, the solvency margin requirements for insurers, net assets of joint stock companies. The second part is related the assessment the insurers by insured. It contains a brief description of idea comprehensive analysis of the insurance company consumers of insurance services, draws conclusions on the adequacy of the legal requirements 
for the financial condition of insurance companies. Methodological principles served as the basis of the system approach, methods of comparative analysis, synthesis, construction of classifications. The study is based on the Russian legal basis, statistical databases of the Russian supervisory authority, practical experience of the author.

\section{BASIC REGULATORY REQUIREMENTS}

FOR THE FINANCIAL CONDITION OF INSURANCE COMPANIES IN RUSSIA

The main item for the fulfillment liabilities to the insured is a stable financial condition of insurance companies. Requirements for the financial condition defined supervisory authority. Starting from September 2013 it is the Central Bank of the Russian Federation. In accordance with Russian legislation the guarantees by the financial stability of the insurer are:

- economically reasonable insurance tariffs;

- insurance reserves, sufficient for the fulfillment obligations under contracts of insurance, coinsurance, reinsurance, mutual insurance;

- equity;

- reinsurance.

Mandatory requirements for the financial condition of insurers include following items:

- the minimum authorized capital;

- solvency margin;

- placement of insurance reserves;

- covering own funds by the assets;

- net assets for Open Joint Stock Company.

Consider the contents of these requirements in details.

The minimum authorized capital was increased by 4 times from January 1 , 2012, and is now $120 \mathrm{mln}$. r. for insurers other than life; $240 \mathrm{mln}$. r. for life insurance and $480 \mathrm{mln}$. r. for reinsurance table 2 . This entailed a sharp decline in the number of insurance companies, table 3, increased market concentration. The total authorized capital of Russian insurers in June 2014 amounted to 219332,4 mln. r. (All-Russian Insurance Association 2014). 
Table 2. Distribution of insurance companies by authorized capital

\begin{tabular}{|l|c|c|c|}
\hline \hline \multicolumn{1}{|c|}{$\begin{array}{c}\text { Authorized capital, } \\
\text { th. rub. }\end{array}$} & $\begin{array}{c}\text { Number of insurance } \\
\text { companies }\end{array}$ & Share & Branches \\
\hline \hline Total & 402 & 0,2 & - \\
\hline Until 20000 & 1 & - & - \\
\hline from 20001 to 40000 & - & 5180 & 115 \\
\hline from 40001 to 60000 & 23 & 6,7 & 196 \\
\hline from 60001 to 80000 & 27 & 1,7 & 84 \\
\hline from 80001 to 100000 & 7 & 85,6 & 4785 \\
\hline More, than 100000 & 344 & & \\
\hline \hline
\end{tabular}

S o u r c e : Federal State Statistics Service.

A steady decline in the number of insurance companies - a consequence of not only increasing requirements to the financial condition, in particular, the size of the authorized capital, but also a set of measures to rid the market of the schemes, unscrupulous insurers. Insurers have to invest their own funds on the terms of diversification, liquidity, repayment and profitability. Insurers do not have the right to invest own funds in the bill of legal entities, individuals and grant loans due its own funds.

Table 3. Number of the Insurance Companies in Russian Federation

\begin{tabular}{|c|c|c|c|c|c|c|c|c|c|}
\hline \hline Year & 2005 & 2006 & 2007 & 2008 & 2009 & 2010 & 2011 & 2012 & 2013 \\
\hline $\begin{array}{l}\text { Number of the insu- } \\
\text { rance companies }\end{array}$ & 1075 & 918 & 869 & 814 & 722 & 640 & 587 & 458 & 402 \\
\hline \hline
\end{tabular}

S o u r c e : own study based on: Federal State Statistics Service, The Central Bank of the Russian Federation.

Solvency margin - in Russia is determined by the type of Solvency 1, when comparing $16 \%$ of the premiums per year and the arithmetic mean of $23 \%$ of payments per three years; the maximum value (standard margin) must exceed the actual (own funds) more than 30\%. If the actual solvency margin exceeds the normative solvency margin less than $30 \%$, the insurer shall submit to the insurance supervision the plan of improvement a financial situation. The plan improvement of a financial position includes activities to ensure compliance with the ratio between the actual and normative dimensions of the solvency margin. 
The calculation of the solvency margin made by insurers on a quarterly basis. Few years there has been discussion about the need and expediency of introduction Solvency-II, are developed a set of indicators of risk assessment of insurance companies, however, now there are only considered solvency margin.

Placement of insurance reserves and covering the own funds by the assets.

Insurance reserves for non-life include (Ministry of Finance of the Russian Federation 2002):

- unearned premium reserve;

- loss reserves:

- reserve declared but unsettled losses;

- reserves for incurred but not reported claims;

- stabilization reserve.

The structure of insurance reserves for life insurance includes the following reserves (Ministry of Finance of the Russian Federation 2009):

- the mathematical reserve;

- reserve maintenance costs of insurance liabilities;

- reserve payments reported but unsettled insurance claims;

- provision of payments of incurred but not reported insurance claims;

- provision of additional payments (insurance bonuses);

- equalization reserve.

Insurance reserves in 2013 amounted 779.4 billion rubles (per year increased by 153.1 billion rubles - 24.4\%), life insurance - 99.7 billion rubles (per year increased by 29.5 billion rubles $-42.0 \%$ ). The ratio of insurance reserves and premiums on life insurance $117.4 \%$; insurance other than life insurance $83.3 \%$, table 4 .

Table 4. Insurance reserves in Russian Federation, mln. r., 2013

\begin{tabular}{|c|c|c|c|c|c|c|}
\hline \hline \multicolumn{2}{|l|}{ Insurance reserves, 31.12.2013 } & \multicolumn{2}{|c|}{ Change of insurance reserves } & $\begin{array}{c}\text { Investment } \\
\text { income }\end{array}$ & $\begin{array}{c}\text { Investment income from insu- } \\
\text { rance reserves }\end{array}$ \\
\hline \hline Total & Life insurance & Total & Life insurance & Total & Total & Life insurance \\
\hline 779413,7 & 99676,1 & 153086,3 & 29494,9 & 582154,7 & 25170,6 & 5681,1 \\
\hline \hline
\end{tabular}

S o u r c e : own study based on: Federal State Statistics Service.

Placement of insurance reserves carried out in accordance with the order of the Ministry of Finance the order of placement of insurance reserves by insurers. Basically it is government securities, deposits, stocks, bonds, real estate. 
Not less than $70 \%$ of insurance reserves must be invested in the Russian Federation. Similar requirements (slightly differ in structure) are required to cover the assets of equity, table 5.

Table 5. The main directions of the investment of insurance reserves and own funds

\begin{tabular}{|l|c|c|}
\hline \hline \multicolumn{1}{|c|}{ Asset } & $\begin{array}{c}\text { Normative for insurance reserves } \\
\text { (not more, than \% to total sum } \\
\text { of insurance reserves) }\end{array}$ & $\begin{array}{c}\text { Normative for own funds } \\
\text { (not more, than \% to maximum } \\
\text { of normative margin of solvency } \\
\text { or minimum authorized capital) }\end{array}$ \\
\hline \hline $\begin{array}{l}\text { Government securities of the Russian } \\
\text { Federation and municipal securities }\end{array}$ & $\begin{array}{c}40-\text { life } \\
30-\text { non life }\end{array}$ & 30 \\
\hline $\begin{array}{l}\text { Bank deposits (deposits), including } \\
\text { certificates of deposit }\end{array}$ & 50 & 20 \\
\hline Shares & 20 & 45 \\
\hline Bonds & 45 & 40 \\
\hline Property & $25-$ life \\
\hline \hline
\end{tabular}

S o u r c e : compiled by author on Ministry of Finance of the Russian Federation (2012); Ministry of Finance of the Russian Federation 2012a.

According to a study by KPMG in 2014 increased interest managers of insurance companies to invest in more observed in the areas of corporate bonds, deposits, currency $(44 \%, 30 \%, 25 \%$ of managers reported an increase in interest, respectively) (KPMG 2014). According to the investment attractiveness of Russia is now in 6th place in the world (EY 2013).

The insurer in accordance with the law organizes internal control and audit. The objectives of internal control are effective and breakeven financial and economic activities, the effectiveness of asset management, the effectiveness of the risk management of the insurer, reliability, completeness, objectivity of accounting, statistical reports, statements in exercise of supervision, compliance workers insurer with ethical norms, opposition to the legalization of proceeds from crime, and terrorist financing. Internal control is carried out management bodies of the insurer, the Audit Commission, the chief accountant, internal auditor, actuary.

Internal auditor verifies the effectiveness of internal control of the insurer, the compliance of insurer activities legislation, rules and standards associations of insurers, compliance with the rules of the internal control of counteraction to legalization of proceeds from crime and terrorist financing, the accura- 
cy, completeness, objectivity, accountability and timeliness of the submission; analyzes the causes of the violations; assesses risk management, feasibility and efficiency of transactions; check the safeguarding of assets; analyzes financial condition of the insurer and measures to prevent the bankruptcy; approves reports on the implementation of the plan to restore solvency.

Failure to comply with the above requirements will result in revocation of the license. In 2012, were revoked 103 licenses from insurance companies, in $2013-36$, for six months in $2014-5$.

\section{THE ASSESSMENT THE INSURERS BY INSURED}

Russian insurants are forced not only trust the opinion of the supervisory authority about the possibility of finding the company on the market and realization of insurance activity, but also to choose a company guided primarily by the implementation of its insurance liabilities. If private persons are forced follow the general information: availability of a license for a period of work in the market, the development of sales networks, quality of sales channels, related services, - the corporate clients are able to evaluate the financial condition of the insurance company in detail, they put forward additional to the legislative requirements.

Author has formed several methods for assessing the financial condition of the insurance company by the insured (for large industrial enterprises of ferrous metallurgy) in different directions with different sets of indicators of financial condition. Several techniques have been tested on the insurance companies - contractors enterprise. In testing involved specialists of enterprise risk management. As a result, the most convenient and informative as a technique for assessing the financial condition of the insurer has been recognized technique in the following areas (table 6):

- capital;

- assets;

- reinsurance;

- solvency;

- profit and profitability;

- the cost of doing business;

- management. 
Table 6. Main characteristics of insurance companies

\begin{tabular}{|c|c|c|c|c|c|c|c|}
\hline $\begin{array}{c}\text { Direction } \\
\text { of } \\
\text { assessment }\end{array}$ & Capital & Assets & Reinsurance & Solvency & $\begin{array}{c}\text { Profit } \\
\text { and } \\
\text { Profitability }\end{array}$ & $\begin{array}{l}\text { Cost } \\
\text { of doing } \\
\text { business }\end{array}$ & $\begin{array}{c}\text { Business } \\
\text { activity, } \\
\text { Manage- } \\
\text { ment }\end{array}$ \\
\hline $\begin{array}{l}\text { Characteri- } \\
\text { stics }\end{array}$ & $\begin{array}{l}\text { Structure, } \\
\text { volume } \\
\text { change of } \\
\text { equity } \\
\text { own } \\
\text { insurance } \\
\text { reserves } \\
\text { loan }\end{array}$ & $\begin{array}{l}\text { Placement } \\
\text { of insurance } \\
\text { reserves } \\
\text { Covering the } \\
\text { assets own } \\
\text { funds } \\
\text { Placement } \\
\text { of available } \\
\text { assets } \\
\text { Investment } \\
\text { policy in } \\
\text { general } \\
\text { Presence } \\
\text { of high-risk } \\
\text { assets } \\
\text { Loans }\end{array}$ & $\begin{array}{l}\text { Availability } \\
\text { reinsurance } \\
\text { program } \\
\text { Payments } \\
\text { under the } \\
\text { reinsurance } \\
\text { contracts } \\
\text { Ratings of } \\
\text { reinsurers } \\
\text { Reinsurance } \\
\text { in Russia }\end{array}$ & $\begin{array}{l}\text { Regulatory } \\
\text { compliance } \\
\text { Solvency for } \\
\text { not insuran- } \\
\text { ce liabilities } \\
\text { Cost loans } \\
\text { of credit } \\
\text { institutions }\end{array}$ & $\begin{array}{l}\text { Profit and } \\
\text { profitability } \\
\text { of insurance } \\
\text { operations } \\
\text { and non-in- } \\
\text { sured } \\
\text { Profit from } \\
\text { insurance } \\
\text { operations } \\
\text { Profitability } \\
\text { of insurance } \\
\text { reserves } \\
\text { ROI as a } \\
\text { whole }\end{array}$ & $\begin{array}{l}\text { Costs of the } \\
\text { proceedings } \\
\text { Commis- } \\
\text { sions to } \\
\text { insurance } \\
\text { agents } \\
\text { Salary of ma- } \\
\text { nagement } \\
\text { Dividends to } \\
\text { shareholders }\end{array}$ & $\begin{array}{l}\text { Volume of } \\
\text { premiums } \\
\text { and pay- } \\
\text { ments } \\
\text { Regional } \\
\text { networks } \\
\text { Sales chan- } \\
\text { nels } \\
\text { The absence } \\
\text { of com- } \\
\text { promising } \\
\text { information } \\
\text { Number of } \\
\text { complaints } \\
\text { by insurants } \\
\text { Bankruptcy } \\
\text { procedures }\end{array}$ \\
\hline $\begin{array}{l}\text { Form of the } \\
\text { original data }\end{array}$ & $\begin{array}{l}\text { Balance } \\
\text { sheet of the } \\
\text { insurer (f.1) } \\
\text { Report on } \\
\text { changes in } \\
\text { equity of } \\
\text { the insurer } \\
\text { (and the net } \\
\text { assets) (f.3) } \\
\text { The insuran- } \\
\text { ce reserves } \\
\text { (f.8-insurer) }\end{array}$ & $\begin{array}{l}\text { Balance } \\
\text { sheet of the } \\
\text { insurer (f.1) } \\
\text { Report on } \\
\text { financial } \\
\text { results of } \\
\text { the insurer } \\
\text { (f. } 2 \text { ) }\end{array}$ & $\begin{array}{l}\text { Reinsurance } \\
\text { operations } \\
\text { (f. 10-insu- } \\
\text { rer) } \\
\text { Report on } \\
\text { financial } \\
\text { results of } \\
\text { the insurer } \\
\text { (f.2) }\end{array}$ & $\begin{array}{l}\text { Balance } \\
\text { sheet of the } \\
\text { insurer (f.1) } \\
\text { Report on } \\
\text { financial } \\
\text { results of } \\
\text { the insurer } \\
\text { (f.2) } \\
\text { The solvency } \\
\text { (f.9-insurer) }\end{array}$ & $\begin{array}{l}\text { Balance } \\
\text { sheet of the } \\
\text { insurer (f.1) } \\
\text { Report on } \\
\text { financial } \\
\text { results of } \\
\text { the insurer } \\
\text { (f.2) } \\
\text { Report on } \\
\text { changes in } \\
\text { equity of } \\
\text { the insurer } \\
\text { (and the net } \\
\text { assets ) (f.3) } \\
\text { The struc- } \\
\text { ture of the } \\
\text { financial } \\
\text { results of } \\
\text { insurance } \\
\text { (f. 11-insu- } \\
\text { rer) }\end{array}$ & $\begin{array}{l}\text { Report on } \\
\text { financial } \\
\text { results of } \\
\text { the insurer } \\
\text { (f.2) } \\
\text { The struc- } \\
\text { ture of the } \\
\text { financial } \\
\text { results of } \\
\text { insurance } \\
\text { (f.11-insu- } \\
\text { rer) }\end{array}$ & $\begin{array}{l}\text { Balance } \\
\text { sheet of the } \\
\text { insurer (f.1) } \\
\text { Statistical } \\
\text { Report №1 } \\
\text { "Data on key } \\
\text { indicators of } \\
\text { insurer" } \\
\text { the branches } \\
\text { and repre- } \\
\text { sentations } \\
\text { (f. 12-insu- } \\
\text { rer) } \\
\text { Share- } \\
\text { holders } \\
\text { (members) } \\
\text { and other } \\
\text { affiliated } \\
\text { entities (f. } \\
\text { 13-insurer) }\end{array}$ \\
\hline
\end{tabular}

S o u r c e : the author's method, has been implemented at OAO "Magnitogorsk Iron \& Steel Works".

All of these measures can be calculated according to the forms, which are published on the website of the insurance supervision (The Central Bank of the Russian Federation 2014) and according to the data in open publications. At present the additional requirements for the financial condition of Russian insurance companies are nominated by enterprises with sufficiently developed comprehensive risk management system. Mostly this is the large credit institu- 
tions, enterprises of energy, metallurgy, fuel and energy complexes. Additional requirements are fixed in the standards, the provisions of the risk policy; the conformity of the insurers these demands - required to be accredited in the insurance programs.

\section{THE OUTCOME OF THE RESEARCH PROCESS AND CONCLUSIONS}

Recently started a discussion on the possible strengthening of state involvement in the insurance market. Such a position seems unproductive. In particular, a clear regulatory compliance with respect to the financial condition of insurance companies, internal and external control and insurance supervision are in able to ensure the insurance liabilities by the market participants. Following the requirements of the financial condition is sufficient for insurance liabilities; all the accounting, financial and statistical reports are published on the websites of companies and online insurance supervision, the regulatory requirements for the financial condition of Russian insurance companies are correspond the requirements of the International Association of Insurance Supervisors and perform basic functions of insurance - to protect consumers, and insurers are able to get all the necessary information.

Thus the main directions of development - prudential oversight, improving the quality of settlement of losses, the formalization of contracts and business processes in general, improve the quality of the insurer's assets, control over the structure and the amount of the cost of doing business.

\section{REFERENCES}

All-Russian Insurance Association. Official Site, http://www.insur-info.ru (accessed: 1.10.2014).

Efimova O.V. (2012). Sustainability Reporting of Company: evaluation information requirements of users. Bulletin of the Russian Peoples' Friendship University. Series: the Economy, no. 4, 75-82.

EY (2013), Investigation of investment attractiveness of Russia. Shaping the Future of Russia, http://www.ey.com/Publication/vwLUAssets/Ras2013-rus/\$FILE/ Ras2013-rus.pdf (accessed: 1.10.2014).

Federal State Statistics Service, Main indicators of activities of insurance companies. Official Site of the Federal State Statistics Service, http:www.gks.ru (accessed: 1.10.2014). 
Jurgens I.Y. (2014), All-Russian Insurance Association. Analytical report "The insurance market in 2014: Challenges and Opportunities". URL: http://autodiscover.ins-union.ru (accessed: 1.10.2014).

KPMG (2014), The new reality: an overview of the insurance market in Russia, July 2014, http://www.kpmg.com/RU/ru/IssuesAndInsights (accessed: 1.10.2014).

Ministry of Finance of the Russian Federation (2002), Order of the Ministry of Finance of the Russian Federation from 11.06.2002 N 51n (eds. From 08.02.2012), On approval of the Regulations for the formation of insurance reserves by insurance other than life insurance.

Ministry of Finance of the Russian Federation (2009), Order of the Ministry of Finance of the Russian Federation of April 9, 2009 N 32n, On approval of the formation of insurance reserves for life insurance.

Ministry of Finance of the Russian Federation (2012), Order of the Ministry of Finance of the Russian Federation of July 2, 2012 N 100n, On Approval of Procedure placement of insurance reserves by insurers.

Ministry of Finance of the Russian Federation (2012a), Order of the Ministry of Finance of the Russian Federation of July 2, 2012 N 101n, On approval of the requirements for the composition and structure of assets accepted to cover the insurer's own funds.

The Central Bank of the Russian Federation, http:www.cbr.ru (accessed: 1.10.2014). 
